\title{
PEPTIDE MAPPING OF THE RIBULOSE BISPHOSPHATE CARBOXYLASE LARGE SUBUNIT FROM THE GENUS OENOTHERA
}

\author{
by \\ ANTHONY A. HOLDER \\ Department of Physiology, Carlsberg Laboratory \\ Gamle Carlsberg Vej 10, DK-2500 Copenhagen, Valby
}

Keywords: Fingerprint, chloroplast genome, fraction 1 protein

A peptide mapping procedure for the peptides derived by chymotryptic digestion of the large subunit of ribulose1,5-bisphosphate carboxylase from Oenothera is described. The peptides were characterized first by ion exchange chromatography and then by thin layer chromatography in a number of solvent systems, using ninhydrin and amino acid specific stains for detection. A comparison of the maps from different Oenothera species revealed considerable similarity between the species but with a small number of differences. The results are discussed in relation to the different chloroplast genomes present in Oenothera.

\section{INTRODUCTION}

Ribulose 1,5-bisphosphate carboxylase (RuBPCase, E.C. 4.1.1.39) is an enzyme that has been extensively used for the study of nuclear-cytoplasmic relationships in the evolution of higher plants and to provide phenotypic markers of the nuclear and chloroplast genomes. Amino acid sequencing of the two types of subunit of RuBPCase provides such markers $(23,28)$, but often other characteristics of the polypeptides which reflect their sequence can be used. Such studies employing isoelectric focusing $(17,20)$ and peptide mapping $(3,13)$ of the enzyme from the genus Nicotiana have shown that the large subunit (MW 55,000) is maternally inherited whereas the small subunit (MW 12,000-15,000) is inherited in a Mendelian fashion. The gene coding for the large subunit has been shown to be localized on chloroplast DNA in maize (6) and Chlamydomonas (9).

Of considerable interest is the amount of genetic variability between chloroplast genomes of different plant species. Recently, restriction endonuclease analysis of chloroplast DNA has shown considerable variation in the total nucleotide sequence (1). Although on the basis of immunological cross reactivity (10) and amino acid composition (26) the RuBPCase large subunit has been regarded as a highly con- 
served structure, primary structural differences in the polypeptides from related species have been indicated by isoelectric focusing $(4,8,17$, $22)$ and peptide mapping studies $(14,15,16)$.

The subgenus Oenothera provides an ideal system to look for intrageneric variation in chloroplast DNA because different chloroplast genome types (plastome types) adapted to particular nuclear genomes are known $(18,24)$. The previous report (12) described the isolation of RuBPCase from Oenothera and a peptide mapping procedure to characterize the tryptic peptides of the two subunits. Because many of the large subunit tryptic peptides were poorly soluble, the peptides derived by chymotryptic digestion of the RuBPCase large subunit are characterized in this study. The resulting chymotryptic peptide fingerprints from 9 Oenothera species are compared and discussed in relation to the chloroplast genome type present in the individual species.

\section{MATERIALS AND METHODS}

\subsection{Plant material}

The investigation was carried out on species representative of the five chloroplast genome types defined by STUbBe $(18,24)$. These were the essentially homozygous lethal-free species with 7 bivalent chromosomes at meiosis, Oenothera hookeri (chloroplast genome I), O.elata Guatemala (chloroplast genome I) and O.argillicola (chloroplast genome $\mathrm{V}$ ); and the following permanent complex heterozygote species which usually have a ring of 14 chromosomes at meiosis: O.strigosa (chloroplast genome 1), O. biennis-1 Citronelle (chloroplast genome II), O. biennis-2 München (chloroplast genome II), O. lamarckiana Schweden (chloroplast genome III), $O$. parviflora-1 atrovirens (chloroplast genome IV) and O. parviflora-2 ammophila (chloroplast genome IV). The seeds were kindly provided by professor W. STUBBE, Botanisches Institut der Universität Düsseldorf, and leaf material was obtained as described previously (12).

\subsection{Enzyme purification and isolation of the RuBPCase large subunit}

RuBPCase was prepared from all the Oenothera species as described previously (12) except that the homogenization and Sepharose 6B gel filtration buffers were those used by MELCHERS et al. (19). The purified protein was S-carboxymethylated and then the subunits were separated by gel filtration in $50 \mathrm{~mm}$-ammonium bicarbonate containing $0.5 \%$ sodium dodecyl sulphate (12). The purified large subunit was used for the subsequent digestion and peptide mapping.

\subsection{Digestion with chymotrypsin}

25mg S-carboxymethylated RuBPCase large subunit was suspended in $50 \mathrm{~mm}$-ammonium bicarbonate and digested with $2 \%(w / w)$ chymotrypsin ( $3 \mathrm{x}$ crystallised and lyophilized, Sigma, USA) at $35^{\circ} \mathrm{C}$. After $3 \frac{1}{2}$ hours the digestion was stopped by adjusting to $\mathrm{pH} 4$ with glacial acetic acid and was subsequently freeze dried.

\subsection{Chymotryptic peptide mapping of RuBPCase large subunit}

The two dimensional peptide mapping procedure described previously (12) was used except that thin layer chromatography (TLC) on silica gel (Type 60 precoated plastic sheets; Merck, Darmstadt, GFR) was used in the second dimension. The peptides were first separated by ion exchange chromatography on a column (19 $\times 0.9 \mathrm{~cm}$ ) of Dowex AG50W-X4 resin using an exponential pyridine acetate gradient. Aliquots from alternate effluent fractions were spotted as a series $5 \mathrm{~mm}$ apart and $10 \mathrm{~mm}$ away from the long edge of a $20 \times 10 \mathrm{~cm}$ TLC plate. Samples were applied in $1.5 \mu 10.05 \mathrm{M}$-pyridine acetate, $\mathrm{pH} 2.5$ or $50 \mathrm{~mm}$-ammonium bicarbonate, approximately $0.5 \mu \mathrm{l}$ at a time with hot air drying between each application. The plate was developed by ascending chromatography using isopropanol-acetic acid-water $(4: 1: 1, \mathrm{v} / \mathrm{v})$ (Solvent A) until the solvent reached the top edge of the 
plate. Each sample was spotted on triplicate plates which were stained either with $0.25 \%$ ninhydrin in acetone, followed, after bleaching with $2 \% \mathrm{HCl}$ in acetone, by the phenanthrenequinone arginine stain (27) and the Pauly reagent for histidine (2) or cadmium ninhydrin (7) followed by 1-nitroso-2-naphthol and $\mathrm{HNO}_{3}$ as a tyrosine stain (7) or cadmium ninhydrin followed by Ehrlich's reagent for tryptophan (21).

For two dimensional chromatography of pooled fractions from the ion exchange column the sample was spotted $8 \mathrm{~mm}$ away from each edge in the corner of a $6.6 \times 6.6 \mathrm{~cm}$ TLC plate. The plate was developed in the first dimension with either Solvent A or with amylalcoholisopropanol-formic acid-water (14:74:6:6, v/v) (Solvent B). After drying in a stream of warm air the plates were developed in the second dimension using either butanol-methanolacetic acid-water-pyridine (45:30:6:24:20, v/v) (Solvent C) or butanol-isopropanol-acetic acidwater-pyridine (10:30:6:24:20 v/v) (Solvent D).

The chromatography was performed in preequilibrated glass tanks using freshly prepared solvents and without prior equilibration of the thin layer plate. For each chromatography a reference mixture of some amino acids and derivatives was spotted on the same plate.

\section{RESULTS}

\subsection{Characterization of the chymotryptic} peptides from Oenothera RuBPCase large subunit

The S-carboxymethylated polypeptide was solubilized by treatment with chymotrypsin and essentially all the resultant peptides were dissolved by the pyridine acetate buffer, $\mathrm{pH} 2.5$ in which they were applied to the Dowex AG50W-X4 column. After the second dimension by thin layer chromatography the peptides separated by ion exchange chromatography were detected by ninhydrin and by amino acid specific stain reagents. Figure 1 shows a typical composite map derived from a triplicate TLC analysis which enabled the use of 4 amino acid specific stains to characterize the chymotryptic peptides derived from $\mathrm{O}$. biennis München. A complex pattern of peptides was obtained and several weak or inconsistent peptides have been arbitrarily omitted from Figure 1. Some peptides eluted in a large volume from the column and were therefore often difficult to visualize, others stained poorly with ninhydrin but were readily detected by a specific amino acid stain. The peptides which stained for specific amino acids were very valuable as landmarks to facilitate subsequent alignment and comparison of the peptide maps from different species.

A number of TLC solvent systems were used to further analyse the peptides, especially those peptides in complex regions where many peptides were only partially resolved. Peptides eluting late from the AG50 column had, in general, a low mobility in the TLC solvent $A$. The application of two dimensional TLC to the relatively simple mixtures of peptides in the judiciously pooled fractions from the ion exchange column was in some instances used to clarify some of the complexity of the peptide map. The application of this approach to the chymotryptic peptides from $\mathrm{O}$. biennis München RuBPCase large subunit is shown in Figure 2. Further peptides could be resolved; for example in pool 12 there are 3 components not separated by chromatography in Solvent $A$. The use of chlorine/starch-KI (7) to detect peptides, a method more sensitive for large peptides and independent of the presence of a free amino group, produced essentially the same pattern of peptides after two dimensional TLC as that obtained with ninhydrin except that the column breakthrough volume (pool 1) contained 2 components not previously detected with ninhydrin. Altogether about 80 peptides were characterized by relative elution position from the ion exchange column, their mobility in a number of TLC solvent systems and their detectability by ninhydrin and amino acid specific stains.

\subsection{Comparison of the chymotryptic peptide maps of different Oenothera species}

The comparison of the two dimensional maps of peptides detected with ninhydrin obtained from a number of Oenothera species is shown in Figure 3. It can be seen that there is an overall similarity in the pattern of peptides. The 


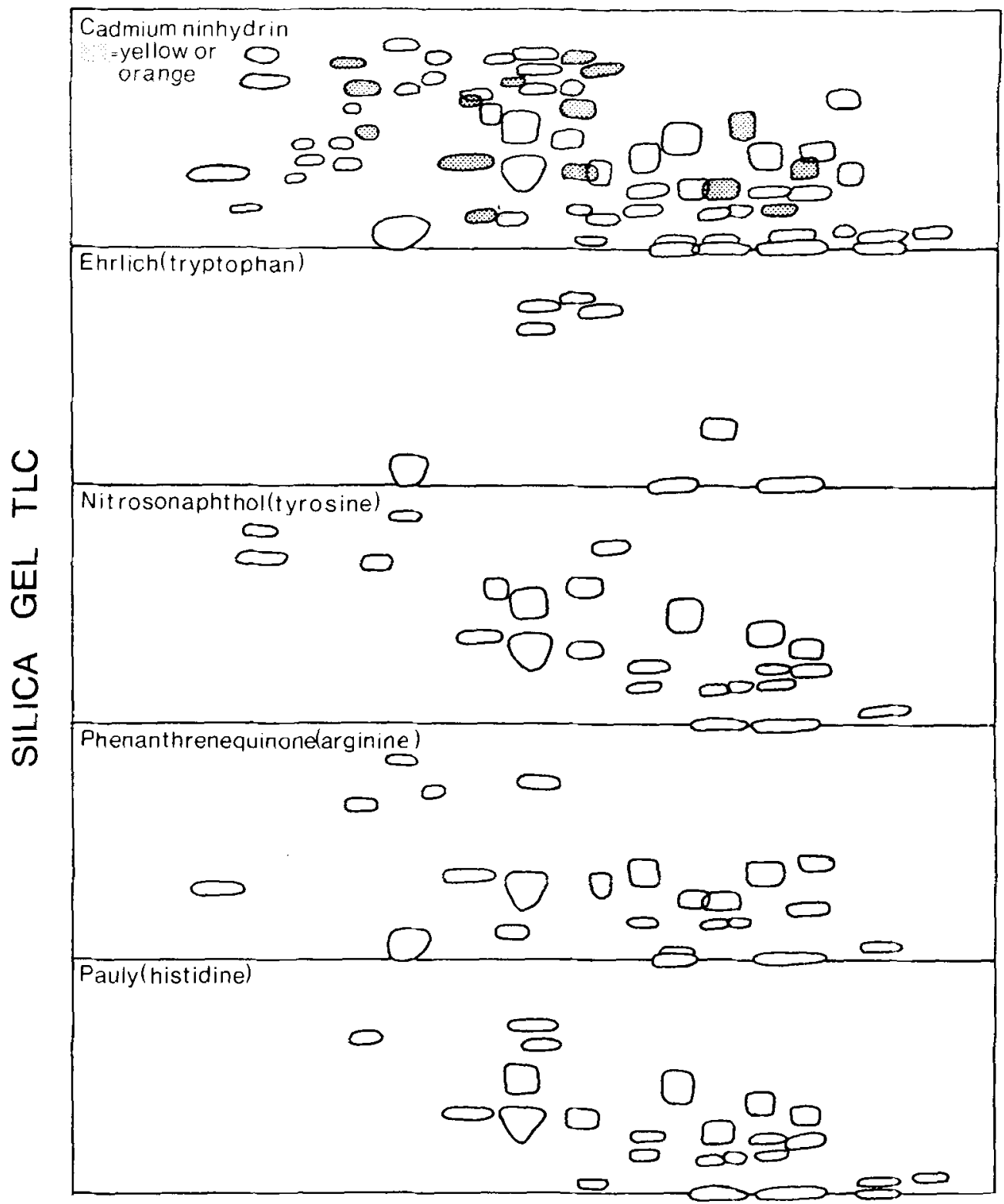

\section{ION EXCHANGE CHROMATOGRAPHY}

Figure 1. Chymotryptic peptide pattern from $\mathrm{O}$. biennis München RuBPCase large subunit after a two dimensional separation and peptide detection with ninhydrin and amino acid specific stains. The peptides were first separated by ion exchange chromatography on AG50W-X4 and then samples from alternate fractions were chromatographed on silica gel using isopropanol-acetic acid-water. Peptides were first detected with ninhydrin and then with specific stains as described in the text. The Pauly reagent locates both histidine- and some tyrosinecontaining peptides. The phenanthrenequinone reagent gives fluorescent spots with some peptides containing aromatic amino acids as well as those containing arginine. 


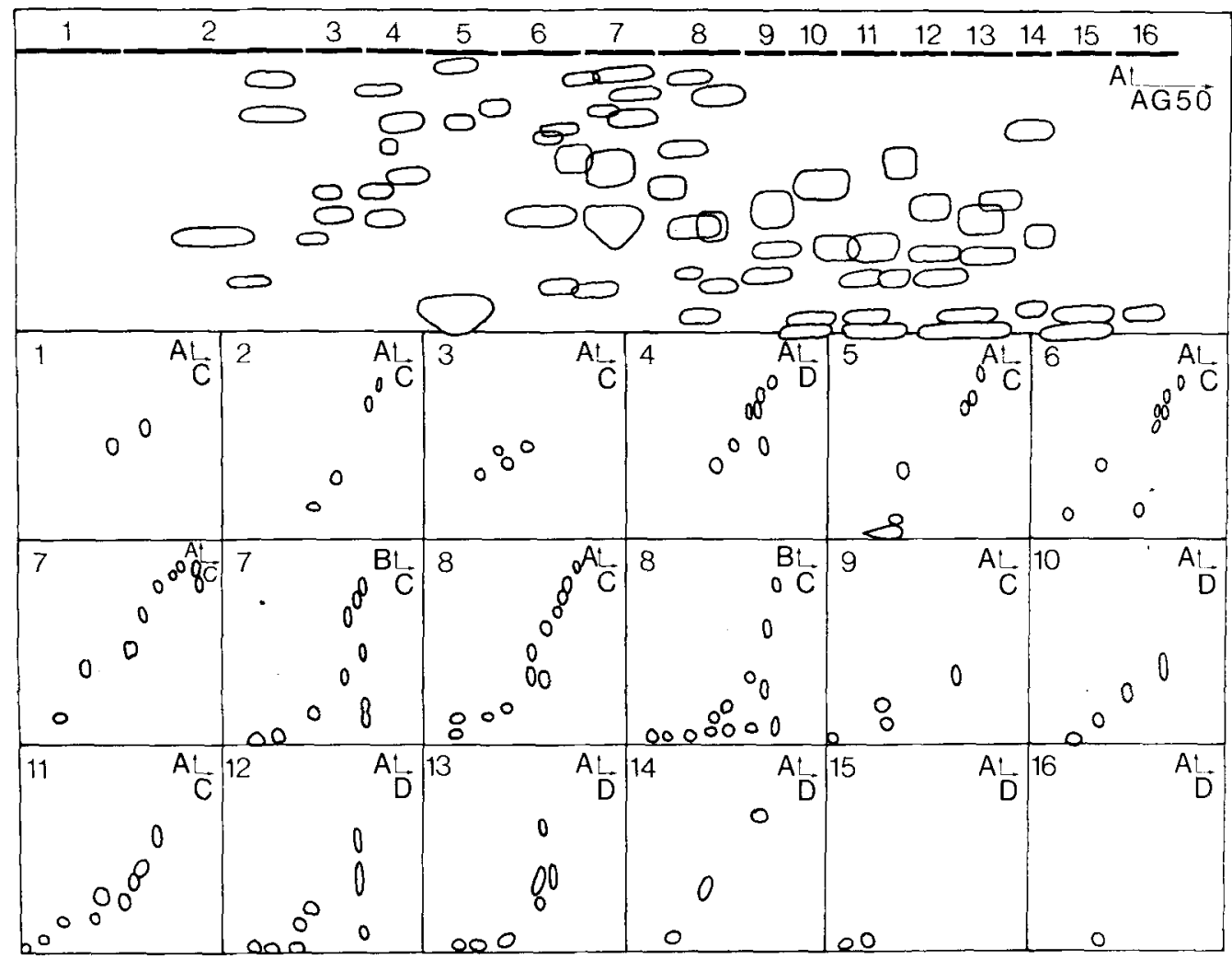

Figure 2. An analysis of peptides in pooled fractions after ion exchange chromatography by two dimensional thin layer chromatography. The peptides from $\mathrm{O}$. biennis München large subunit were pooled as indicated by the bars on the basis of the peptide map shown in Figure 1 and then the 16 pools were analyzed. For two dimensional chromatography the sample was applied at the bottom left-hand corner of each plate which was developed with either isopropanol-acetic acid-water (Solvent A) or amylalcohol-isopropanol-formic acid-water (Solvent B) in the first dimension and then at right angles with either butanol-methanol-acetic acid-water-pyridine (Solvent C) or butanol-isopropanol-acetic acid-water-pyridine (Solvent D). The peptides were located with ninhydrin except those in pool 1 which were only detected with $\mathrm{Cl}_{2} /$ starch-KI.

actual elution position of the peptides from the column was not constant and was sensitive to small variations in the compositions of the pyridine acetate buffers, although the elution behaviour relative to other peptides was much more constant. Several peptides which were faint and variable are not shown in Figure 3. There was always some variation and some peptides which were apparently absent from the primary fingerprint were visible after two dimensional TLC. The shaded areas represent the expected position of peptides clearly absent in some species but present in others. For example, peptide $B$ is recorded as missing in $O$. hookeri, $O$. strigosa, $O$. lamarckiana and $O$. argillicola but present in all the other species.

The number of clearly detectable differences was small. The distribution of 4 peptides chosen for analysis among the products from the different species is shown in Table I. No differences were observed between the two biennis species which were also identical to $O$. elata. Similarly the fingerprints of $O$. strigosa and $O$. lamarckiana were identical and the maps of the 
Table I

\begin{tabular}{|c|c|c|}
\hline Species & $\begin{array}{l}\text { Chloroplast } \\
\text { genome }\end{array}$ & $\begin{array}{l}\text { Presence or } \\
\text { absence of } \\
\text { peptides A to D. }\end{array}$ \\
\hline hookeri & I & $A^{-} B^{-} C^{+} D^{+}$ \\
\hline strigosa & I & $A-B-C-D^{+}$ \\
\hline elata Guatamala & I & $A^{-} B^{+} C^{+} D^{+}$ \\
\hline biennis-1 Citronelle & II & $A^{-} B^{+} C^{+} D^{+}$ \\
\hline biennis-2 München & II & $A^{-} B^{+} C^{+} D^{+}$ \\
\hline lamarckiana Schweden & III & $A^{-}-B^{-} C^{-} D^{+}$ \\
\hline parviflora-1 atrovirens & IV & $\mathrm{A}^{+} \mathrm{B}^{+} \mathrm{C}^{+} \mathrm{D}^{-}$ \\
\hline parviflora-2 ammophila & IV & $A^{+} B^{+} C^{+} D^{-}$ \\
\hline argillicola & $\mathrm{v}$ & $A^{+} B^{-} C^{+} D^{-}$ \\
\hline
\end{tabular}

two subspecies of O. parviflora were indistinguishable. Peptide A (stained only with ninhydrin) was present only on the fingerprints of $O$. parviflora and $O$. argillicola. The peptide maps of $O$. parviflora and $O$. argillicola had a second feature in common, the absence of $\mathrm{D}, \mathrm{a}$ peptide of low mobility that stained for tryptophan on the other fingerprints. However, $O$. argillicola lacked the peptide $B$ which stained orange with cadmium ninhydrin and also contained tryptophan. Peptide B was also missing from the maps of $O$. hookeri, $O$. strigosa and $O$. lamarckiana. Peptide $\mathrm{C}$ which stained for tyrosine was missing from both $O$. strigosa and $O$. lamarckiana.

\section{DISCUSSION}

The primary structure of the large subunits of RuBPCase from some Oenothera species have been compared by peptide mapping. Some of

Figure 3. Comparison of the chymotryptic peptide maps of RuBPCase large subunit from Oenothera species containing different chloroplast genome types (I-V). The peptides were characterized as described for Figure 1 and the peptides located with ninhydrin are displayed. The expected positions of 4 peptides $A$ to $D$ are shown by the shaded areas on the fingerprints where they were absent. the limitations of this approach have been discussed previously (12) and clearly reproducibility is essential when digestion is performed with an enzyme of broad specificity such as chymotrypsin. As expected many fragments were obtained, the majority of them were probably small. The use of small peptides increases the sensitivity of the comparative peptide mapping procedure but the complexity of the mixture of peptide products requires a separation system capable of high resolution. Because of the difficulty in interpretation of a complex peptide pattern the analysis has been restricted to four peptides which were clearly distinguishable. It has not yet been possible to isolate all these peptide fragments and analyse their amino acid sequences nor to determine the $\mathrm{N}$ terminal sequence of the intact polypeptide chain which is blocked to automatic sequencing (B. MARTIN and A. Holder, unpublished). Until precise comparative sequence information is available the conclusions which can be drawn from peptide mapping must be regarded as tentative.

Although the peptide maps from all the species of large subunit were very similar there was a small number of differences detected. These differences are likely to be due to amino acid replacements and indicate that evolutionary divergence of the large subunit gene has occured within the genus Oenothera, in agreement with the expected polymorphisms of the chloroplast DNA to cause the nuclear genomechloroplast genome incompatibilities. However, it is clear from Table I that the peptide patterns of the large subunits from species with the same chloroplast genome type as defined by these incompatibility relationships are not necessarily identical. For example, although hookeri, strigosa and elata all have chloroplast genome $\mathrm{I}$, strigosa lacks peptide $\mathrm{C}$ which is present in hookeri and elata; hookeri and strigosa lack peptide $B$ which is present in elata. No differences in the peptide maps of strigosa and lamarckiana could be clearly demonstrated although the chloropast genomes are classified as type I and type III, respectively. The two biennis species have identical peptide patterns and both have type II plastids. O. parviflora ammophila and parviflora atrovirens large sub- 
units could not be differentiated from one another and indeed both contain chloroplast genome IV. The large subunit of argillicola (chloropast genome $\mathrm{V}$ ) has a similar fingerprint to that of parviflora with just one difference detected.

The molecular basis of the genome incompatibility in Oenothera is unknown and therefore its relationship to the primary structure of RuBPCase is unclear. However, the peptide mapping studies show that the RuBPCase large subunit products from different incompatibility types have features in common and yet also show variation within a single group. The evolution of Oenothera has been extensively studied (5) and STUBbe (25) has discussed the role of the chloroplast genome in the evolution of this genus. The chloroplast genome IV is compatible with all nuclear genomes and considered to be primitive whereas chloroplast genomes $\mathrm{I}$ and $\mathrm{V}$ are adapted to only a single nuclear genome. Chloroplast genomes IV and $\mathrm{V}$ are considered to be related which is also suggested by the fingerprint analysis. It is tempting to suggest that the differences detected in the chloroplast gene coding for the large subunit of RuBPCase have arisen by single amino acid substitutions and recombination. A determination of the precise amino acid sequence differences and their effect upon the assembly and function of the oligomeric enzyme are clearly necessary to increase our understanding of this intriguing system.

\section{ACKNOWLEDGEMENTS}

I wish to thank professor DITER VON WETTSTEIN for provision of laboratory facilities during these studies and for reading the manuscript. Support from the Wellcome Trust by a Wellcome/Carlsberg Travelling Research Fellowship and from the Royal Society by a European Science Exchange Program Fellowship is gratefully acknowledged.

\section{REFERENCES}

1. AtChison, B. A., P. R. Whitfield \& W. BottomLEY: Comparison of chloroplast DNAs by specific fragmentation with EcoR1 endonuclease. Molec. gen. Genet. 148, 263-269 (1976)
2. Bennett, J. C.: Paper chromatography and electrophoresis; special procedures for peptide maps. Methods Enzymol. 11, 330-339 (1967)

3. Chan, P. H. \& S. G. WILDMan: Chloroplast DNA codes for the primary structure of the large subunit of Fraction 1 protein. Biochim. Biophys. Acta 277, 677-680(1972)

4. Chen, K., J. C. Gray \& S. G. Wildman: Fraction 1 protein and the origin of polyploid wheats. Science 190, 1304-1306 (1975)

5. Cl.eland, R. E.: Oenothera cytogenetics and evolution. Academic Press, London (1972)

6. Coen, D. M., J. R. Bedbrook, L. Bogorad \& A. RICH: Maize chloroplast DNA fragment encoding the large subunit of ribulose bisphosphate carboxylase. Proc. Nat. Acad. Sci. (USA) 74, 5487-5491 (1977)

7. Dawson, R. M. C., D. C. Elliott, W. H. Elliott \& K. M. JONES: Data for biochemical research. 2nd Ed. Oxford University Press pp. 525-534 (1969)

8. Gatenby, A. A. \& E. C. Cocking: Fraction 1 protein and the origin of the European potato. Plant Sci. Letts. 12, 177-181 (1978)

9. Gelvin, S., P. Heizmann \& S. H. Howell: Identification and cloning of the chloroplast gene coding for the large subunit of ribulose 1,5-bisphosphate carboxylase from Chlamydomonas reinhardtii. Proc. Nat. Acad. Sci. (USA) 74, 3193-3197 (1977)

10. Gray, J. C. \& R. G. O. KeKWICK: An immunological investigation of the structure and function of ribulose 1,5-bisphosphate. Eur. J. Biochem. 44, 481-489 (1974)

11. Gray, J. C., S. D. Kung, S. G. Wildman \& S. J. SHEEN: Origin of Nicotiana tabacum L. detected by polypeptide composition of Fraction 1 protein. Nature 252, 226-227 (1974)

12. Holder, A. A.: Ribulose 1,5-diphosphate carboxylase from Oenothera: purification and a peptide mapping procedure for the subunits. Carlsberg Res. Commun. 41, 321-334 (1976)

13. Kawashima, N. \& S. G. Wildman: Studies on Fraction 1 protein. IV. Mode of inheritance of the primary structure in relation to whether chloroplast or nuclear DNA contains the code for a chloroplast protein. Biochim. Biophys. Acta 262, $42-49$ (1972)

14. Kawashima, N., Y. Tanabe \& S. IwaI: Similarities and differences in the primary structure of Fraction 1 proteins in the genus Nicotiana. Biochim. Biophys. Acta 371, 417-431 (1974)

15. Kawashima, N. \& Y. Tanabe: Comparison of the primary structure of the large and small subunits 
of Fraction 1 protein from Solanaceae and other families. Biochem. Syst. Ecol. 2, 193-199 (1975)

16. Kawashima, N., Y. Tanabe \& S. Iwal: Origin of Nicotiana tabacum detected by primary structure of Fraction 1 protein. Biochim. Biophys. Acta 427, 70-77 (1976)

17. Kung, S. D.: Tobacco Fraction 1 protein: a unique genetic marker. Science 191, 429-434 (1976)

18. Kutzelnigg, H. \& W. Stubbe: Investigations on plastome mutants in Oenothera. 1. General considerations. Sub-Cell Biochem. 3, 73-89 (1974)

19. Melchers, G., M. D. SACristán \& A. A. HOLDER: Somatic hybrid plants of potato and tomato regenerated from fused protoplasts. Carlsberg Res. Commun. 43, 203-218 (1978)

20. Sakano, K., S. D. Kung \& S. G. Wildman: Identification of several chloroplast DNA genes which code for the large subunit of Nicotiana Fraction 1 proteins. Mol. gen. Genet. 130, 91-97 (1974)

21. SMITH, I.: Colour reactions on paper chromatograms by a dipping technique. Nature 171, 43-44 (1953)

22. Steer, M. W. \& D. Kernoghan: Nuclear and cytoplasmic genome relationships in the genus
Avena: analysis by isoelectric focusing of ribulose bisphosphate carboxylase subunits. Biochem. Genet. 15, 273-286 (1977)

23. Strøbek, S., G. C. Gibbons, B. Haslett, D. BOULTER \& S. G. WILDMAN: On the nature of the polymorphism of the small subunit of ribulose 1,5-diphosphate carboxylase in the amphidiploid Nicotiana tabacum. Carlsberg Res. Commun. 41, 335-343 (1976)

24. Stubie, W.: Genetische Analyse des Zusammenwirkens von Genom und Plastom bei Oenothera. Z. Vererb. 90, 288-298 (1959)

25. Stubie, W.: The role of the plastome in evolution of the genus Oenothera. Genetica 35, 28-33 (1964)

26. Takabe, T. \& T. Akazawa: Molecular evolution of ribulose-1,5-bisphosphate carboxylase. Plant \& Cell Physiol. 16, 1049-1060(1975)

27. Yamada, S. \& H. A. Itano: Phenanthrenequinone as an analytical reagent for arginine and other monosubstituted guanidines. Biochem. Biophys. Acta 130, 538-540 (1966)

28. Wettstein, D. von, C. Poulsen \& A. A. Holder : Ribulose-1,5-bisphosphate carboxylase as a nuclear and chloroplast marker. Theor. Appl. Genet. in press (1978) 